\title{
Quality of groundwater in the Kwahu West district of Ghana
}

\author{
*Marian Asantewah Nkansah, Juliet Ofosuah and Sandra Boakye
}

\author{
Department of Chemistry, \\ Kwame Nkrumah University of Science and Technology, Kumasi - Ghana \\ Email*: maan4gr@yahoo.co.uk
}

\begin{abstract}
The quality of ground water in the Kwahu West District of Ghana was determined by the use of physicochemical parameters together with trace metal contamination as indices of quality. Standard methods for physicochemical determinations were employed. Atomic Absorption Spectrophotometer was also used for the measurement of nickel (Ni), lead (Pb), zinc ( $\mathrm{Zn})$, copper $(\mathrm{Cu})$ and iron (Fe). Nitrate, Chloride, Alkalinity and Phosphate were also determined photometrically. Results were compared with global averages for freshwater and international water quality standards for drinking water, World Heath Organisation, (WHO). Evaluation of physicochemical parameters revealed that the water samples were within the maximum permissible limits for consumption. All elements except iron, lead and nickel, were well within the safety limits recommended by WHO. The low level of industrialization in the study area has kept the water relatively free from heavy metal contamination.
\end{abstract}

Keywords: Contamination, physicochemical, trace metals, ground water

\section{INTRODUCTION}

Water is the most important natural resource in the world since without it life cannot probably exist and industry cannot operate. Unlike many raw materials there is no substitute for water in many of its uses (Aidoo, 2003).

Groundwater is the most important source of the domestic, industrial and agricultural water supply in the world. The preference for ground water to surface water must be due to the purification of the latter prior to distribution (Adeyeye and Abulude, 2004).

A number of factors influence water chemistry. Gibbs, (1970) proposed that rock weathering, atmospheric precipitation, evaporation and crystallization control the chemistry of water. The influence of geology on chemical water quality is widely recognized (Gibbs, 1970; Langmuir, 1997; Lester and Birkett, 1999). The influence of soils on water quality is very complex and can be ascribed to the processes controlling the exchange of chemicals between the soil and water (Hesterberg, 1998).

The water chemistry of the groundwater will mainly consist of inorganic chemicals and suspended solids as a result of urban run-offs (McGregor, et al., 2000).

The quality of water may be described according to their physico-chemical and micro-biological characteristics. The quality of ground water is never constant; it is constantly changing in response to daily, seasonal and climatic rhythms. For effective maintenance of water quality through appropriate control measures, continuous monitoring of large number of quality parameters is crucial because the changes in properties of water have far-reaching implications directly to the biota and indirectly to man (Kara and Comlekci, 2004). Water quality data are thus, essential for the implementation of responsible water quality regulations, for characterizing and remediating contamination and for the protection of the health of humans and ecosystem.

Developing countries are witnessing changes in ground water which constitute another source of portable water. The water pollution by heavy metals has become a question of considerable public and scientific concern in the light of the evidence of their toxicity to human health and biological systems (Anazawa et al., 2004). In the United States, many thousands of wells have been closed in the late 20th century because of contamination by various toxic substances (Halt, 2008). Industrial activities within the catchment impact negatively on groundwater quality therefore rendering it unwholesome for domestic purposes. Essentiality and toxicity of trace metals in water depends on the concentration of the metal; below a certain level they could be considered as essential for biochemical processes, but in the case of a high accumulation in organism, intoxication 
may occur. The toxicity of metals is dependent on their solubility and this in turn depends on $\mathrm{pH}$ and on the presence of different types of anions and other cations. The level of trace metals in the environment at a high percent depends on the extent of pollution. Trace elements in natural waters can be present in different physico-chemical forms, varying in size, charge and density properties. Knowledge of speciation is essential for understanding the transport, distribution, and biological uptake of trace elements in the environment.

The present research was carried out to determine the physicochemical parameters and levels of trace metals in groundwater from the Kwahu West district. This planned research will be helpful to assess the impact of mining and industrial activities on the quality of surrounding water bodies.

\section{MATERIALS AND METHODS}

Description of study area: The Kwahu-West District is located in the Eastern Region of Ghana and it lies between latitudes $6^{\circ} 30^{\prime}$ North and $7^{\circ}$ North and longitudes $0^{\circ} 30^{\prime} \mathrm{West}$ and $1^{\circ} \mathrm{West}$ of the equator, covering an area of about 414 square kilometers
(Figure 1). The district capital, Nkawkaw, is located about 214 kilometers North-West of Accra. The district is bounded to the north by the Kwahu-South District, to the west by Asante-Akim South District, to the east, it is bounded by the Fanteakwa District and to the south by the Birim North and Atiwa Districts. The district lies within the wet-semi equatorial region. As such, it experiences a double maximal rainfall pattern with average monthly relative humidity ranging between $75 \%$ and $80 \%$ during the two rainy seasons. Mean monthly temperature values as high as $30^{\circ} \mathrm{C}$ are often recorded between the month of March and April but declines to $26{ }^{\circ} \mathrm{C}$ in August. The District comes under the influence of two air masses namely the tropical maritime air mass (MT) and the tropical continental (CT). The tropical maritime air mass hits the district twice a year thereby causing the two rainy seasons. The two occasions are May to August and then September to October. Between the months of November and March, the district is affected by tropical continental air mass making the area warm and dry.

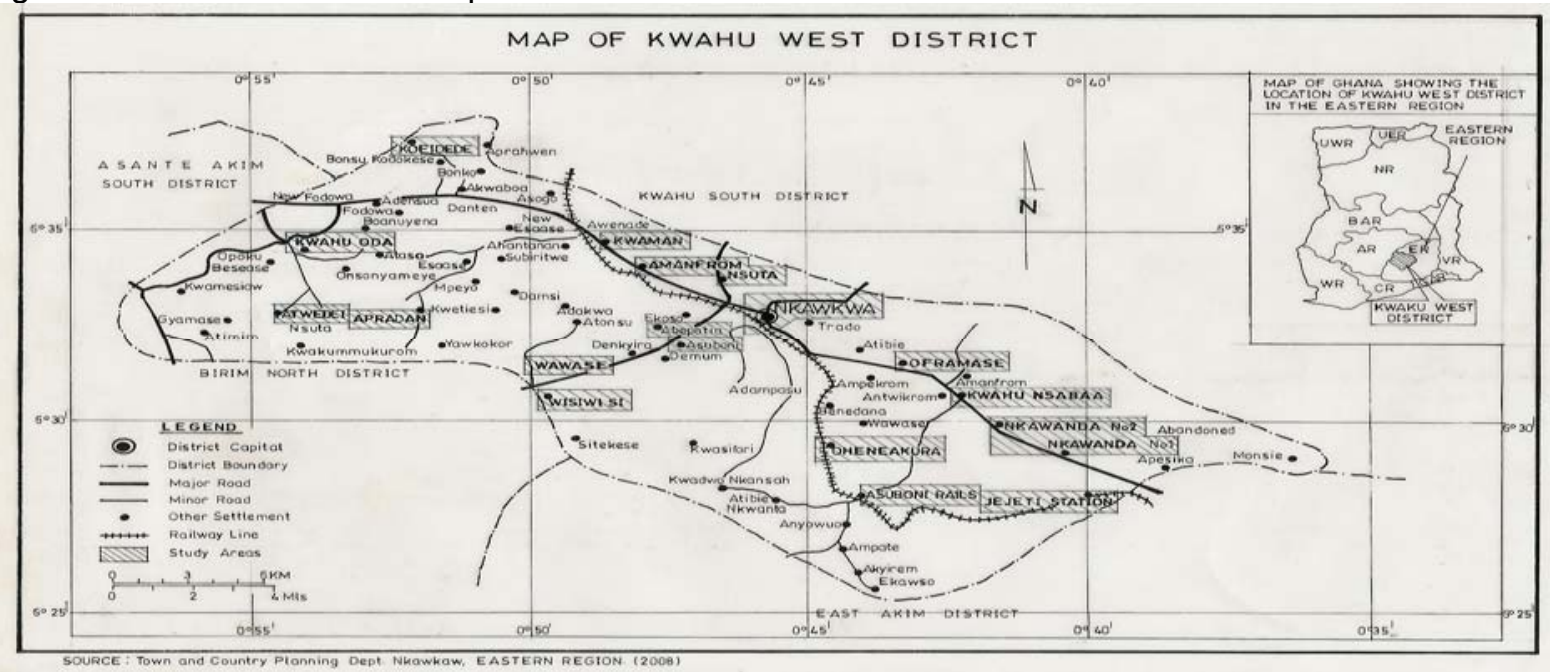

Fig 1: Map of the Kwahu West District showing sample locations

\section{SAMPLING}

Water samples were collected in plastic containers previously cleaned by washing in non-ionic detergent, rinsed with tap water and later soaked in $10 \% \mathrm{HNO}_{3}$ for 24 hours and finally rinsed with deionised water prior to usage.

Sample containers at the point of sampling were rinsed with sampled water three times before filling. The samples were labelled and transported to the laboratory and stored in the refrigerator at about $4^{\circ} \mathrm{C}$ prior to analysis.

\section{MEASUREMENT OF PHYSICOCHEMICAL PARAMETERS}

pH was determined with a Beaker, model $3150 \mathrm{pH}$ meter (53800)-JENWAY) with a temperature sensor. Analysis of samples was carried out at $25^{\circ} \mathrm{C}$. The $\mathrm{pH}$ meter was calibrated with buffer solutions of $\mathrm{pH} 4.01$ 
7.00 and 10.00 prepared from capsules of $\mathrm{BDH}$ buffer before use.

The total conductivity and Total Dissolved Solids (TDS) of sample were measured by a conductivity meter with cell constant of 1.0. Instrument was kept clean and standardized with $\mathrm{KCl}$ solution before use. The electrode was rinsed with distilled water and lowered into the sample in the beaker. The conductivity in $\mu \mathrm{S} / \mathrm{cm}$ of the sample was recorded.TDS was also measured by selecting the TDS key while the electrode remained in the water sample used to measure conductivity, and the TDS value in $\mathrm{mg} / \mathrm{I}$ was recorded.

Turbidity values were taken using Hanna instrument; LP2000 Turbid meter. The Turbid meter was calibrated with the 1000 NTU, 100 NTU, 10 NTU, and 0.02 NTU standards. The cuvette was rinsed three times with the sample to be tested. The light shield cap was replaced and all outside surfaces cleaned and made dry. The cuvette was pushed firmly into the optical well and index to the lowest reading. The NTU values were measured by pressing and releasing the arrow button and the value recorded.

Alkalinity was determined by titration with a standard acid to the phenolphthalein end point (APHA, 1998).

Determination of total hardness was carried out by EDTA titration to erichrome black T end point (APHA, 1998).

Chloride content was determined by agentometric titration.

Phosphate and nitrate were determined by colour development and UV-Visible spectrometric measurements of absorbance. Concentrations were measured using calibration curves of the respective standards according to the Beer-Lambert's Law.

\section{Metal measurements}

Atomic absorption spectrophotometer (AAS), Perkin Elmer 5100 model with deuterium background corrector was used in the determination of trace metals. Determinations were carried out in

air / acetylene flame using hollow cathode lamps of each metal used as radiation source. Prior to analysis the AAS was calibrated according to the manufacturer's manual. Calibration curves were established using internal and external standards. Recovery values were quantitative $(>95 \%)$ for all the metals. Limits of detection of the analysed metals were determined as thrice standard deviation of the lowest detectable concentrations by the AAS from the mean of three replicate analyses. Procedural blanks and duplicates were run alongside as part of the quality assurance program

\section{DISCUSSION}

The samples analyzed were taken from different communities to be representative of the water situation in the Kwahu west district. In this view, discussion of the results is intended to tell the quality of the groundwater body used in the whole district. Because of the large size of some of the communities or suburbs, two or more samples were picked from different sites, to represent that area within the district.

The $\mathrm{pH}$ of the water, ranged from 6.67 to 7.35 . Values of the samples picked from the same area fell within the general range quoted for the district. An average value of 6.9 , which falls within the acceptable WHO range of $7.5+/-1$, represents a fair distribution of the Hydrogen in concentration in the water.

It can be said that, the levels of calcium and magnesium ions in the water samples were very low (probably insignificant), since the values of total hardness, which is chiefly dependent on the concentrations of Calcium and Magnesium metals, never exceeded $20 \mathrm{ppm}$. Total Hardness recorded values as low as $7.00 \mathrm{ppm}$, with an average value of $11.37 \mathrm{ppm}$, representing that of the whole district. Since hardness generally enters groundwater as its percolates through minerals containing calcium and magnesium, it could be discussed that, the groundwater in the district, either does not percolate through such minerals at all, or percolates through minerals with very low concentrations of these constituents. Some of the users of the groundwater interviewed, said that, users do not have problems with the water, lathering easily with soap. This claim is confirmed by the relatively low total hardness which falls within the soft category of classification ( 0 - $60 \mathrm{ppm}$ ), as set by $\mathrm{WHO}$. 
Am. J. Sci. Ind. Res., 2010, 1(3): 578-584

RESULTS

Physicochemical, nutrient and trace metal analyses were performed on 30 representative groundwater samples from the Kwahu west district between October 2008 to March 2009. The outcome has been presented in tables 1 and 2 .

Table 1: Physicochemical parameters

\begin{tabular}{|c|c|c|c|c|c|c|c|c|c|}
\hline $\begin{array}{l}\text { SAMPLE I } \\
\text { WHO LIMIT }\end{array}$ & $\begin{array}{c}\mathrm{pH} \\
6.5-8.5\end{array}$ & $\begin{array}{c}\text { Conductivity } \\
\mu S / \mathrm{cm} \\
1500\end{array}$ & $\begin{array}{l}\text { TDS, } \\
\text { mg/L } \\
1000\end{array}$ & $\begin{array}{c}\text { Turbidity } \\
\text { NTU } \\
5.0\end{array}$ & $\begin{array}{c}\text { T. Hardness } \\
\text { mg/L } \\
500\end{array}$ & $\begin{array}{l}\text { Chloride } \\
\text { mg/L } \\
250\end{array}$ & $\begin{array}{c}\text { Alkalinity } \\
\text { mg/L } \\
150\end{array}$ & $\begin{array}{c}\text { Nitrate I } \\
\mathrm{mg} / \mathrm{L} \\
10.0\end{array}$ & $\begin{array}{c}\text { Phosphate } \\
\text { / mg/L } \\
-\end{array}$ \\
\hline AM1 & 6.89 & 68.4 & 46 & 1.03 & 9.00 & 12.41 & 142.50 & 2.433 & 2.50 \\
\hline AM2 & 6.67 & 18.0 & 12 & 0.00 & 10.00 & 10.64 & 32.50 & 2.266 & 1.25 \\
\hline AM3 & 6.82 & 51.4 & 35 & 0.00 & 10.00 & 26.59 & 70.00 & 1.766 & 2.50 \\
\hline AS1 & 6.74 & 25.7 & 18 & 1.00 & 9.00 & 17.73 & 33.30 & 2.908 & 2.50 \\
\hline AS2 & 6.75 & 25.8 & 18 & 0.61 & 10.00 & 10.64 & 37.50 & 6.697 & 2.50 \\
\hline AS3 & 6.96 & 78.5 & 53 & 0.30 & 13.00 & 40.77 & 112.50 & 5.115 & 2.50 \\
\hline AB1 & 6.74 & 47.8 & 33 & 1.34 & 9.00 & 23.04 & 47.50 & 2.773 & 2.92 \\
\hline AB2 & 6.95 & 65.9 & 45 & 0.53 & 10.00 & 12.40 & 140.00 & 7.974 & 2.50 \\
\hline NS1 & 6.84 & 50.1 & 35 & 0.42 & 13.00 & 19.50 & 87.50 & 0.539 & 2.50 \\
\hline NS2 & 6.87 & 50.5 & 35 & 0.18 & 8.00 & 17.73 & 82.50 & 2.783 & 2.50 \\
\hline NKK1 & 6.79 & 75.1 & 51 & 0.05 & 10.00 & 57.40 & 20.00 & 1.898 & 3.33 \\
\hline NKK2 & 6.74 & 74.0 & 50 & 0.07 & 10.00 & 40.77 & 22.51 & 5.441 & 2.50 \\
\hline NK1 & 6.67 & 85.9 & 58 & 0.00 & 20.00 & 56.72 & 45.00 & 0.546 & 2.08 \\
\hline NK2 & 6.69 & 75.0 & 51 & 0.00 & 10.00 & 53.18 & 22.50 & 8.039 & 3.75 \\
\hline NK3 & 6.80 & 87.7 & 60 & 0.00 & 12.00 & 54.95 & 65.00 & 7.615 & 2.08 \\
\hline OF1 & 6.86 & 45.4 & 31 & 0.00 & 10.00 & 5.32 & 110.00 & 4.049 & 2.50 \\
\hline OF2 & 6.87 & 42.1 & 29 & 0.00 & 13.00 & 7.09 & 107.50 & 3.227 & 3.75 \\
\hline OF3 & 6.86 & 41.9 & 29 & 0.00 & 20.00 & 3.55 & 107.50 & 2.671 & 3.33 \\
\hline OF4 & 6.86 & 45.8 & 29 & 0.00 & 18.00 & 1.77 & 100.00 & 3.388 & 2.50 \\
\hline 0F5 & 6.86 & 42.0 & 31 & 0.00 & 11.00 & 8.86 & 102.50 & 4.184 & 4.17 \\
\hline NW & 6.84 & 58.2 & 39 & 0.24 & 8.00 & 15.95 & 37.50 & 1.470 & 1.25 \\
\hline JS & 7.03 & 36.8 & 25 & 0.00 & 9.00 & 5.32 & 17.50 & 4.184 & 2.50 \\
\hline KN & 7.35 & 8.49 & 5 & 0.00 & 7.00 & 24.82 & 25.00 & 2.447 & 1.25 \\
\hline OK & 6.82 & 59.7 & 41 & 0.17 & 10.00 & 3.55 & 170.00 & 1.924 & 2.08 \\
\hline AR & 6.94 & 37.0 & 25 & 0.00 & 9.00 & 28.36 & 77.50 & 7.875 & 3.75 \\
\hline AD & 6.97 & 37.0 & 18 & 0.00 & 8.00 & 1.77 & 77.50 & 0.125 & 2.92 \\
\hline DT & 7.20 & 58.3 & 39 & 0.00 & 15.5 & 54.95 & 20.00 & 1.441 & 3.75 \\
\hline KD & 7.07 & 46.9 & 33 & 0.00 & 13.00 & 8.86 & 90.00 & 1.612 & 3.33 \\
\hline KO & 7.11 & 41.8 & 29 & 0.00 & 10.00 & 3.55 & 105.00 & 2.414 & 1.25 \\
\hline AT & 7.32 & 99.2 & 67 & 0.00 & 16.5 & 14.18 & 17.50 & 1.934 & 3.33 \\
\hline
\end{tabular}


Am. J. Sci. Ind. Res., 2010, 1(3): 578-584

Table 2: Trace metal content of water samples

\begin{tabular}{|c|c|c|c|c|c|}
\hline $\begin{array}{l}\text { SAMPLE NAME } \\
\text { WHO LIMIT, ppm }\end{array}$ & $\begin{array}{l}\mathrm{Ni}(\text { mean } \pm S D) \\
0.02\end{array}$ & $\begin{array}{l}\mathrm{Pb}(\text { mean } \pm S D) \\
0.3\end{array}$ & $\begin{array}{l}\text { Zn (mean } \pm S D) \\
3.0\end{array}$ & $\begin{array}{l}\text { Cu (mean } \pm S D) \\
2.0\end{array}$ & $\begin{array}{l}\text { Fe (mean } \pm S D) \\
0.02\end{array}$ \\
\hline AM1 & $(0.039 \pm 0.006)$ & $0.142 \pm 0.021$ & $0.023 \pm 0.006$ & $0.161 \pm 0.003$ & $0.310 \pm 0.003$ \\
\hline AM2 & $0.040 \pm 0.008$ & $0.161 \pm 0.026$ & $0.021 \pm 0.000$ & $0.105 \pm 0.001$ & $0.978 \pm 0.009$ \\
\hline AM3 & $0.049 \pm 0.008$ & $0.170 \pm 0.012$ & $0.008 \pm 0.002$ & $0.097 \pm 0.002$ & $0.329 \pm 0.006$ \\
\hline AS1 & $0.173 \pm 0.011$ & $0.145 \pm 0.012$ & $0.115 \pm 0.011$ & $0.082 \pm 0.004$ & $1.255 \pm 0.006$ \\
\hline AS2 & $0.129 \pm 0.004$ & $0.157 \pm 0.025$ & $0.061 \pm 0.049$ & $0.633 \pm 0.013$ & $0.351 \pm 0.008$ \\
\hline AS3 & $0.107 \pm 0.006$ & $0.178 \pm 0.008$ & $0.056 \pm 0.039$ & $0.116 \pm 0.000$ & $0.335 \pm 0.011$ \\
\hline AB1 & $0.255 \pm 0.009$ & $0.149 \pm 0.010$ & $0.137 \pm 0.057$ & $0.076 \pm 0.004$ & $1.332 \pm 0.003$ \\
\hline AB2 & $0.179 \pm 0.005$ & $0.131 \pm 0.030$ & $0.174 \pm 0.003$ & $0.119 \pm 0.004$ & $0.575 \pm 0.005$ \\
\hline NS1 & $0.257 \pm 0.005$ & $0.122 \pm 0.031$ & $0.056 \pm 0.002$ & $0.173 \pm 0.008$ & $1.428 \pm 0.010$ \\
\hline NS2 & $0.099 \pm 0.005$ & $0.127 \pm 0.020$ & $0.033 \pm 0.004$ & $0.061 \pm 0.009$ & $0.521 \pm 0.013$ \\
\hline NKK1 & $0.246 \pm 0.008$ & $0.107 \pm 0.011$ & $0.197 \pm 0.005$ & $0.308 \pm 0.004$ & $1.251 \pm 0.002$ \\
\hline NKK2 & $0.099 \pm 0.008$ & $0.111 \pm 0.027$ & $0.198 \pm 0.003$ & $0.134 \pm 0.005$ & $1.227 \pm 0.013$ \\
\hline NK1 & $0.142 \pm 0.002$ & $0.156 \pm 0.022$ & $0.154 \pm 0.011$ & $0.307 \pm 0.255$ & $1.594 \pm 0.003$ \\
\hline NK2 & $0.290 \pm 0.003$ & $0.114 \pm 0.011$ & $0.124 \pm 0.036$ & $0.160 \pm 0.007$ & $1.614 \pm 0.007$ \\
\hline NK3 & $0.256 \pm 0.006$ & $0.183 \pm 0.037$ & $0.142 \pm 0.005$ & $0.126 \pm 0.002$ & $0.084 \pm 0.007$ \\
\hline OF1 & $0.093 \pm 0.004$ & $0.270 \pm 0.015$ & $0.180 \pm 0.007$ & $0.122 \pm 0.007$ & $0.338 \pm 0.011$ \\
\hline OF2 & $0.100 \pm 0.008$ & $0.137 \pm 0.022$ & $0.087 \pm 0.055$ & $0.199 \pm 0.001$ & $0.069 \pm 0.012$ \\
\hline OF3 & $0.139 \pm 0.008$ & $0.156 \pm 0.034$ & $0.030 \pm 0.006$ & $0.075 \pm 0.002$ & $0.101 \pm 0.008$ \\
\hline OF4 & $0.101 \pm 0.006$ & $0.139 \pm 0.015$ & $0.015 \pm 0.005$ & $0.155 \pm 0.004$ & $0.299 \pm 0.004$ \\
\hline OF5 & $0.236 \pm 0.003$ & $0.614 \pm 0.015$ & $0.034 \pm 0.004$ & $0.104 \pm 0.002$ & $1.548 \pm 0.016$ \\
\hline NW & $0.239 \pm 0.006$ & $0.129 \pm 0.022$ & $0.047 \pm 0.002$ & $0.102 \pm 0.006$ & $2.232 \pm 0.022$ \\
\hline JS & $0.269 \pm 0.004$ & $0.104 \pm 0.007$ & $0.033 \pm 0.006$ & $0.168 \pm 0.002$ & $1.561 \pm 0.024$ \\
\hline KN & $0.224 \pm 0.012$ & $0.139 \pm 0.025$ & $0.047 \pm 0.006$ & $0.122 \pm 0.003$ & $0.557 \pm 0.011$ \\
\hline OK & $0.255 \pm 0.007$ & $0.134 \pm 0.064$ & $0.027 \pm 0.005$ & $0.082 \pm 0.007$ & $1.680 \pm 0.014$ \\
\hline AR & $0.413 \pm 0.009$ & $0.112 \pm 0.022$ & $0.027 \pm 0.002$ & $0.546 \pm 0.008$ & $1.025 \pm 0.012$ \\
\hline AD & $0.269 \pm 0.008$ & $0.188 \pm 0.015$ & $0.388 \pm 0.004$ & $0.351 \pm 0.008$ & $1.561 \pm 0.004$ \\
\hline DT & $0.270 \pm 0.009$ & $0.162 \pm 0.010$ & $0.015 \pm 0.003$ & $0.329 \pm 0.008$ & $1.521 \pm 0.024$ \\
\hline KD & $0.203 \pm 0.005$ & $0.123 \pm 0.018$ & $0.001 \pm 0.006$ & $0.065 \pm 0.006$ & $0.560 \pm 0.020$ \\
\hline KO & $0.249 \pm 0.006$ & $0.088 \pm 0.007$ & $0.000 \pm 0.008$ & $0.055 \pm 0.005$ & $1.245 \pm 0.014$ \\
\hline AT & $0.267 \pm 0.008$ & $0.151 \pm 0.047$ & $0.002 \pm 0.002$ & $0.108 \pm 0.004$ & $1.371 \pm 0.013$ \\
\hline
\end{tabular}

Direct measurement of conductivity is potentially a very sensitive procedure for measuring ionic concentrations, since conductivity depends on ionic concentration, their mobility etc. The limiting ionic conductivities at $25^{\circ} \mathrm{C}$ is in the order; $\mathrm{H}^{+}>\mathrm{Na}^{+}>\mathrm{K}^{+}$, for singly charged cations. $\mathrm{Ca}^{2+}$ $>\mathrm{Mg}^{2+}>\mathrm{Cu}^{2+}>\mathrm{Zn}^{2+}$, for doubly charged metals. $\mathrm{OH}>$ $\mathrm{F}^{-}$etc, $\mathrm{CO}_{3}{ }^{2-}>\mathrm{SO}_{4}{ }^{2-}$ and $\mathrm{PO}_{4}{ }^{3-}$ for singly, doubly and triply charged anions respectively.

From the $\mathrm{pH}$ values, it could be deduced that there is a very small concentration of hydrogen ions present. The same could be said of calcium and magnesium ions, looking at the very low values of total hardness. From the results on trace metals, copper and zinc happens to be the only metals with concentrations below their WHO set limits.

Hardness is a measure of calcium and magnesium in the form of their carbonates and sulphates. Since their concentrations are small, it could be deduced that, the concentrations of carbonate and sulphate are comparatively small. These are the probable reasons why conductivity, recorded low values ranging from 8.49 to $99.24 S / \mathrm{cm}$, with an average of $52.704 S / \mathrm{cm}$. This value is even far below the molar conductivity of hydrogen ions alone $\left(349.8 \Omega^{-1} / \mathrm{cm}^{2} / \mathrm{mol}\right)$ in water.

From the discussion above, alkalinity which depends chiefly on the concentrations of carbonates, bicarbonates and hydroxide ions, is not expected to have very high values. This deduction is confirmed by the fact that, alkalinity, which has a standard WHO acceptable value of $200 \mathrm{ppm}$ had values which ranged from 17.5 to $142.5 \mathrm{ppm}$, with an average of $70.86 \mathrm{ppm}$. These values tell of relatively low concentration of carbonates, bicarbonates and hydroxides. The highest alkalinity values were recorded for the samples picked from OF and the lowest, for JS and AT.

Turbidity, a measure of how clear the water is, recorded very low values, ranging from 0.00 to $1.34 \mathrm{NTU}$, with eighteen of the samples; below detection limit 
(indicating complete clarity).This gives a reflection of the total suspended solids to which turbidity is inversely related. Turbidity is also an indication of clay or other inert suspended particles in drinking water. Total dissolved solids in milligram per liter, recorded values that ranged from 5 to $67 \mathrm{ppm}$.

The concentration of chloride ion, ranged from 1.77 to $57.40 \mathrm{ppm}$, with an average value of $21.41 \mathrm{ppm}$. Compared to the WHO acceptable value of $250 \mathrm{ppm}$, the levels of chloride concentration can be tolerated, since they can cause no harm to consumers. These low concentrations also confirm the earlier discussion on conductivity.

The concentrations of Nitrate determined for the samples, ranged from 0.125 to $7.875 \mathrm{ppm}$ with an average value of $2.120 \mathrm{ppm}$. It could be discussed that, none of the samples recorded a value that exceeds the acceptable value of $10 \mathrm{ppm}$. With an average value of $2.120 \mathrm{ppm}$, which is far below the tolerable value and also represents the nitrate level of the groundwater bodies in the district, it could be said that, disorder due to nitrate, are not likely to be encountered by users of the water. Phosphate also recorded an average value of $2.652 \mathrm{ppm}$, from a range of 1.25 to $4.17 \mathrm{ppm}$.

According to (lode 1992), a heavy metal is a chemical element with a specific gravity that in at least, 5 times the specific gravity of water, which is 1.0 at $4^{\circ} \mathrm{C}$. However in medicine, heavy metals are loosely defined to include all toxic metals, irrespective of their atomic weight (John, 2002). In the light of these definitions, the metals determined in this project work, fall into the heavy or toxic metal category e.g. Iron has a specific gravity of 7.9 , Lead $=11.34$. In this reference, some of these metals, in tolerable concentrations, are very beneficial to consumers. Iron for example, is made a portion of some multivitamin drugs and products. On the other side, they become toxic when in excess or not, they are not metabolized by the body and they accumulate in the soft tissues. In cooperation with the U.S Environmental Protection Agency (EPA), the Agency for Toxic Substances and Disease registry (ATDR), has compiled a priority list called the Top 20 hazardous Substance. On this list, Lead $(\mathrm{Pb})$ remains second to arsenic. Lead happens to be the only metal amongst the five, which is believed to have no known vital or beneficial effect on organisms. (Lane et al:, 2000)

The average values recorded for the metals are; $\mathrm{Ni}$ (0.1896), $\mathrm{Pb}$ (0.0811), $\mathrm{Fe}(0.9617)$ and $\mathrm{Cu}(0.175)$ all in $\mathrm{ppm}$. From the values listed in Table $2 \mathrm{e}$, it could be inferred that, Zinc and copper, recorded average values that are below the maximum allowable, as set by the World Health organization, which are $3 \mathrm{ppm}$ and $2 \mathrm{ppm}$ respectively. The highest value, recorded for Zinc was
$0.388 \mathrm{ppm}$, for $A D$ whereas, the Highest value recorded for copper was $0.633 \mathrm{ppm}$, for AS. These might be attributed to natural existence in the earth, since there are so far no known anthropogenic factors that could introduce these metals into the water bodies.

Whereas Zinc and Copper recorded values below their maximum allowable values, metals like iron, with an average concentration of $0.962 \mathrm{ppm}$, exceeded the WHO Limit of $0.3 \mathrm{ppm}$. From the table of results, only four of the thirty samples recorded values that were below $0.3 \mathrm{ppm}$. Some of the samples recorded values as high as $2.232 \mathrm{ppm}(\mathrm{NW})$, whereas the others ranged between $0.31 \mathrm{ppm}$ to $1.68 \mathrm{ppm}$. This actually presents a high risk to consumers. Since there are no known industries in the district to contribute to the high levels of iron by means of industrial effluent, anthropogenic factors could be attributed to Sewage, land fill Leachate and wear and tear from rejected machine, cars ( hardware) etc. These levels of iron are likely to form deposits within pipes (in case where pipes are used to draw the water), and break off as black particles that give an unpleasant appearance and taste to the water. Iron can also cause rust flakes and cause staining in laundry.

Lead $(\mathrm{Pb})$, on the other hand also recorded an average value that exceeded the $\mathrm{WHO}$ tolerable value of 0.01 $\mathrm{ppm}$. Actually, none of the thirty samples recorded a value below $0.01 \mathrm{ppm}$. The range was from 0.088 to $0.188 \mathrm{ppm}$. This shows the presence of relatively high distribution of lead in the district. It is evident that, Lead is used in paints (as pigment), PVC Plastics, Pencils, batteries, Pesticides etc, which happens to be the Human activities that introduce Lead into the environment. Since the communities are farming areas, it appears that, the use of pesticides is likely to be the greatest cause of the high levels of Lead in the water. The careless use of fuels like petrol can also be a factor contributing to the high levels of lead in the earth affecting the water bodies. According to the oxford dictionary of chemistry, fifth edition, $\mathrm{Pg} 281$, lead in Petrol and metal ions, can leach by acid rain, and introduce lead and other metals into water bodies.

The last of the metals determined, Nickel, also recorded an average value above the WHO allowable limit of 0.2 $\mathrm{ppm}$. Nickel recorded values within the range of 0.03 $\mathrm{ppm}$ to $0.290 \mathrm{ppm}$, with an average value of 0.1896 $\mathrm{ppm}$. From the range quoted, it could be seen that, none of the samples recovered a value that is below the tolerable value of $0.02 \mathrm{ppm}$. This value compared to lead, represents the extent to which Nickel is also widely distributed in the district. It presents a view of the risks to which consumers of the water are exposed.Larger doses of Nickel are carcinogenic and toxic affecting among others, the skin, bones and teeth of consumers (Ron et al., 2001). The concentration of the heavy or 
toxic metals analyzed, nickel, lead, Zinc and Copper, recorded values below $0.2 \mathrm{ppm}$ even though Nickel and lead with these seemingly small values, exceeded their maximum tolerable values, as set by the World health organization $(\mathrm{WHO})$ for drinking water .From the values, three metals $(\mathrm{Ni}, \mathrm{Pb}, \mathrm{Fe})$, recorded individual and average values that exceeded their allowable limits. For some heavy metals, toxic levels can be a concentration just above the background concentration naturally found in nature.

Scrap metal from the work of blacksmiths, pesticides used by the farmers and the rocky nature of the district, among several other reasons are likely to be the cause of the high levels of metals, widely distributed in the earth, affecting the well water bodies.

Pollution could also be due to the availability of trace metals in the cement and other materials (e.g. Iron rods), used to smoothen and decorate the inside of the wells. These sources have a continual access to the water and can really affect the water. Mention can also be made of the fact that the history of this district is such that there were wars in the olden days that involved the use of ammunitions and this could be a source of pollution by metals like lead etc.

\section{CONCLUSION}

In the light of the parameters determined, it can be concluded that, users of the groundwater body in the Kwahu West district of the Eastern Region are not likely to have any adverse effect as far as parameters like $(\mathrm{pH}$, alkalinity, conductivity, total hardness, total dissolved solids, nitrate, phosphate, turbidity, copper, zinc and chloride) are concerned. This is because, these parameters recorded values that were below or within their allowable ranges.

On the other hand, effects due to $\mathrm{Ni}(0.093-0.413 \mathrm{ppm})$, $\mathrm{Pb}(0.088-0.270 \mathrm{ppm})$ and $\mathrm{Fe}(0.069-1.689 \mathrm{ppm})$ are likely to be encountered because almost all the samples recorded values that exceeded their maximum WHO allowable limits for these metals. The maximum value recorded for lead, $(0.270 \mathrm{ppm})$, exceeded the WHO limits $(0.01 \mathrm{ppm})$. Also for Nickel, the maximum value recorded $(0.413 \mathrm{ppm})$, exceeded the WHO limit $(0.02$ ppm)

However it is highly recommended that further work be done to verify these levels of Iron, Nickel and Lead as well as other microbiological indicators so that the necessary treatment can be done on the water before consumption.

\section{ACKNOWLEDGEMENT}

The authors wish to extend their appreciation to the Department of Chemistry, Kwame Nkrumah University of Science and Technology, Kumasi-Ghana for the use of their facilities for this research.

\section{REFERENCES}

Adeyeye E.I, and Abulude F.O., (2004). Analytical assessments of some surface and ground water resources in lle-Ife, Nigeria. J. Chem. Soc. Nig. Ed 29: 98-103

Aidoo Sylverster. (2003). Quality of SurfaceWater, River Birim as a case study.Department of Chemistry, KNUST. p 34

American Public Health Association (APHA) (1992). Standard methods for analysis of water and waste water. $18^{\text {th }}$ Ed. Washington D.C.

Anazawa, K., Kaido, Y.,Shinomura, Y., Tomiyasu, T. \& Sakamoto, H. (2004). Heavy-metal distribution in River waters and sediments around a "Firefly Village'e, Shikoku, Japan: Application of multivariate analysis. Analytical Sciences, 20:79-84.

Gibbs, R. J. (1970). Mechanisms controlling world water chemistry. Science 170: 1088-1090.

Halt John. (2008). Water Pollution. Microsoft student Encarta

Hesterberg, D. (1998). Biogeochemical cycles and processes leading to changes in mobility of chemicals in soils. Agric. Ecosystem Environ. 67: 121-133.

Kara, C., \& Comlekci, U. (2004).Journal of KSU 7:1.

Lester, J.N. and Birkett, J.W. (1999). Microbiology and Chemistry for Environmental Scientists and Engineers, $\mathrm{E}$ and FN Spoon, New York. Management, Office of Water Quality, Assessment Branch, Surveys Section, Indianapolis. (2nd edn.) Pp.143-147.

McGregor, D.F.M., Thompson, D.A. and Simon, D. (2000). Water quality and \# management in peri- urban Kumasi, Ghana'. Case Study 16 inland-Water Linkages in Rural Watersheds. FAO electronic workshop, FAO, Rome. 